\title{
Marketing en het hart voor de zaak, ofwel het meetbare belang van de gevoelsmatige binding in relaties tussen klanten en organisaties
}

Citation for published version (APA):

Lemmink, J. G. A. M. (1999). Marketing en het hart voor de zaak, ofwel het meetbare belang van de gevoelsmatige binding in relaties tussen klanten en organisaties. Maastricht University. https://doi.org/10.26481/spe.19991015jl

Document status and date:

Published: 15/10/1999

DOI:

10.26481/spe.19991015jl

Document Version:

Publisher's PDF, also known as Version of record

Please check the document version of this publication:

- A submitted manuscript is the version of the article upon submission and before peer-review. There can be important differences between the submitted version and the official published version of record.

People interested in the research are advised to contact the author for the final version of the publication, or visit the DOI to the publisher's website.

- The final author version and the galley proof are versions of the publication after peer review.

- The final published version features the final layout of the paper including the volume, issue and page numbers.

Link to publication

\footnotetext{
General rights rights.

- You may freely distribute the URL identifying the publication in the public portal. please follow below link for the End User Agreement:

www.umlib.nl/taverne-license

Take down policy

If you believe that this document breaches copyright please contact us at:

repository@maastrichtuniversity.nl

providing details and we will investigate your claim.
}

Copyright and moral rights for the publications made accessible in the public portal are retained by the authors and/or other copyright owners and it is a condition of accessing publications that users recognise and abide by the legal requirements associated with these

- Users may download and print one copy of any publication from the public portal for the purpose of private study or research.

- You may not further distribute the material or use it for any profit-making activity or commercial gain

If the publication is distributed under the terms of Article 25fa of the Dutch Copyright Act, indicated by the "Taverne" license above, 


\section{Marketing en het hart voor de zaak}

ofwel het meetbare belang van de gevoelsmatige binding in relaties tussen klanten en organisaties

$$
\text { Jos Le m m in } k
$$


Illustratie omslag: Geluksamulet "seven sisters", eind $19 \mathrm{e}$ eeuw, India. 


\section{Marketing en het hart voor de zaak}

ofwel het meetbare belang van de gevoelsmatige binding in relaties tussen klanten en organisaties

Rede

in verkorte en vrije vorm uitgesproken

bij de aanvaarding van het ambt van hoogleraar in de bedrijfseconomie en bedrijfskunde, in het bijzonder marketing en marktonderzoek, aan de Faculteit der Economische Wetenschappen en Bedrijfskunde van de Universiteit Maastricht op vrijdag 15 oktober 1999

door

dr. Jos G.A.M. Lemmink 


\section{Inhoud}

1. Hart voor de zaak

2. Het begrijpen van de ervaring van consumenten

3. Marketing prestatiemaatstaven

4. Marketing managementvelden

5. Marketing managementvelden en recente ontwikkelingen 18

5.1. Beter begrijpen van ervaringen van de consument 19

5.2. De bouding van bet personeel 24

5.3. Marketing resultaten 25

6. Conclusies 27

$\begin{array}{ll}\text { 7. Dankwoord } 29 & 29\end{array}$

Literatuurlijst 


\section{Hart voor de zaak}

Hart voor de zaak hebben houdt in dat je iets toegedaan bent. Een gevoel van verbondenheid met de zaak hebben en zelfs zo sterk dat je bereid bent de zaak naar derden toe te behartigen. Dit is zeker niet een eenmalig gevoel dat snel weer verdwijnt, maar een gevoel dat over een langere periode standhoudt. Een voorbeeld hiervan is het zaken doen met een vaste autodealer zo positief ervaren, dat je een overtuigd pleitbezorger wordt van diens diensten en service. Het is voor een aanbieder niet meer voldoende om alle aandacht te richten op het beter en efficiënter dan de concurrentie tegemoet komen aan de behoeften van consumenten, door middel van een zogenaamde marktoriëntatie (Kohli \& Jaworski 1990). De moderne visie op relaties behelst dat dit een te beperkte visie is en gaat daarom verder. De anbieder realiseert zich dan dat er sprake moet zijn van lange termijn relaties met consumenten en gaat op zoek naar de factoren die deze relatie bepalen. $\mathrm{Z}_{\text {ij }}$ moet dus zeer goed de preferenties en gedragingen van consumenten kennen en, sterker nog; in staat zijn te leren van het consumentengedrag om ook op langere termijn in te kunnen spelen op veranderende behoeften om zaken te blijwen doen met die consumenten. Immers, relaties kenmerken zich door wederzijds commitment op zakelijke en gevoelsmatige gronden, frequente contacten. tussen consument en aanbieder, het afnemen van goederen en diensten (transacties) en het van elkaar leren in de meest ruime zin van het woord. Relaties met klanten zijn inherent dynamisch. Die dynamiek komt tot uiting bij zowel de aanbieder als de vrager van producten en diensten. Aan de ene kant veranderen behoeften en wensen van klanten, aan de andere kant wordt het aanbod van producten en diensten constant aangepast. Als het goed is draagt de aanbieder zorg voor het juiste aanbod van producten en diensten op het juiste moment. We concluderen dat organisaties het aanbod van producten en diensten steeds dienen aan te passen en vervolgens in staat moeten zijn de rela- 
tie in stand te houden vis-à-vis de concurrentie. Steeds is daarbij de beleving van de consument van het product zelf, het gebruik van het product en de dienstverlening en service rond het product doorslaggevend voor het succes (zie ook Davis \& Meyer 1998).

Het belang van de beleving van de consument en de resultaten van marketinginspanningen zijn terug te vinden in de onderzoeksprioriteiten van het gezaghebbende Amerikaanse Marketing Science Institute (MSD) voor 1998-2000 (Marketing Science Institute 1997). MSI presenteerde een lijst met 15 onderzoeksprioriteiten. Twee steken er met kop en schouders bovenuit en worden als zeer belangrijk gekwalificeerd: understanding the customer experience en marketing metrics and performance measures. Naar mijn opvatting is het begrijpen en leren kennen van ervaringen van klanten een zeer belangrijke input voor het nemen van marketingbeslissingen. Beslissingen die uiteindelijk moeten leiden tot hogere financiële en niet-financiële resultaten van de onderneming. In deze oratie wordt getracht een brug te slaan tussen het begrijpen van de ervaringen van consumenten door het management van de onderneming en de resultaten van de daarop gebaseerde marketinginspanningen. Daarbij zal ik een nieuwe set van marketing managementvelden onderscheiden die samen het hart vormen voor de onderneming, en die een uitstekende bron zijn voor toekomstig wetenschappelijk onderzoek. Bovendien zal blijken dat deze velden alles te maken hebben met het onderhouden van een gevoelsmatige binding in relaties tussen klanten en organisaties. Eerst wordt het begrijpen van de ervaringen van consumenten nader toegelicht en ingevuld, daarna wordt aandacht besteed aan de verzameling van marketing prestatiemaatstaven.

\section{Het begrijpen van de ervaring van consumenten}

Understanding the customer experience impliceert de noodzaak van een multidisciplinair perspectief op de ervaringen van de consument rond de aankoop van producten. Als er geen sprake is van aankoop van een 
fysiek product, maar gebruik wordt gemaakt van een aangeboden dienst door een klant is deze ervaring te vertalen naar de interactie met één of meer medewerkers van de organisatie. Hoewel ook bij de aankoop van fysieke producten advies en assistentie van personeel aanwezig is. Met name bestudering vanuit "organisatiegedrag", en vanuit de sociologie en psychologie leidt tot het beter begrijpen van tevredenheid bij consumenten. Deze verworven kennis toegepast op de ervaringen van klanten tijdens aankoopsituaties, dienstverleningssituaties of interacties door middel van het Internet of andere communicatiemiddelen (fax, telefoon) kan meer inzicht geven in de processen en de percepties daarvan. Daarom is er meer studie nodig naar de interactie tussen klant en anbieder op micro niveau, bijvoorbeeld gedurende een balieservice door medewerkers, interacties met verko. pers en interacties via Internet.

\section{Marketing prestatiemaatstaven}

Sinds jaar en dag gelden winst, marktaandeel en omzet als prestatiemaatstaf voor ondernemingen en ook voor marketinginspanningen. Daaraan kan je zien hoe het met de organisatie gaat of liever gezegd is gegaan. Een zoektocht naar andere, meer innovatieve criteria levert een aantal andere maatstaven (marketing metrics and performance measures) op: bijvoorbeeld kwaliteit, tevredenheid en loyaliteit. De beoordelingen op deze criteria zijn veelal subjectief en zijn derhalve ook afhankelijk van degene die de prestaties beoordeelt: de consument, het contactpersoneel of het management. In de meest zuivere vorm zouden consumenten in staat moeten worden gesteld kwaliteit en tevredenheid aan te geven. Het lijkt zinvol nog verder te kijken dan tevredenheid, kwaliteit of loyaliteit aan het merk of de onderneming. Een aantal onderzoeken (zie voor een overzicht Oliver 1997) bevestigt het sterke verband tussen kwaliteit, tevredenheid en loyaliteit enerzijds en winst anderzijds. Hierbij moet wel worden vermeld dat deze onderzoeken afzien van financiële en boekhoudkundige effecten op de 
winst. Deze studies zijn dus ceteris paribus, waarbij de overige invloeden constant worden verondersteld. Achtereenvolgens beschouwen we nu het verband tussen kwaliteit c.q. tevredenheid en winst, en loyaliteit en winst:

Kwaliteit, tevredenbeid en winst

Hoge kwaliteit van producten en van de organisatie stelt ondernemingen in staat hogere, $z$ gn. premium prijzen te vragen met hogere marges. Daarbij komt nog dat er in de regel kostenbesparingen zijn te behalen omdat het aantal fouten in het productie of dienstverleningsproces gereduceerd wordt en op de kosten van het herstellen van die fouten wordt bespaard. In de regel hebben bedrijven met hogere kwaliteit een betere reputatie bij consumenten en ook in distributiekanalen. In een aantal studies wordt de directe link tussen kwaliteit en winst bevestigd (Aaker \& Jacobson 1994, Capon, Farley \& Hoenig 1990). Tevredenheid heeft een direct verband met winst, door het effect van herhalingsaankopen. Tevreden consumenten nemen meer producten af, zijn minder prijsgevoelig en hebben minder aandacht voor aantrekkelijke proposities van concurrenten (Anderson, Fornell \& Lehmann 1994, Kalyanaram \& Little 1994). Een interessante ontwikkeling is dat er software beschikbaar is die het verband tussen investeringen in $\mathrm{kwaliteit} \mathrm{(ook} \mathrm{in} \mathrm{de} \mathrm{moeilijk} \mathrm{meetbare} \mathrm{gebieden} \mathrm{van}$ dienstverlening) en de opbrengst (winst) expliciet maakt voor ondernemingen (Rust, Zahorik \& Keiningham 1995). Dit is een uitstekend hulpmiddel voor het management om keuzes te maken uit alternatieve aanwending van middelen voor $\mathrm{kwaliteitsverbeteringen.}$

\section{Loyaliteit en winst}

Een tevreden en trouwe klant heeft waarde voor de onderneming. Deze zogenaamde lifetime value van klanten en de waarde van die loyaliteit zijn voorbeelden van prestatiemaatstaven. Loyaliteit leidt 
tot een regelmatige stroom van toekomstige klanten. Een gegarandeerde toekomstige klantenpopulatie geeft ondernemingen de middelen om strategieën te ontwikkelen, marketing instrumenten in te zetten en aanvallen van concurrenten te pareren (Anderson, Fornell 8 Lehmann 1994, Aaker 1992). Een voorbeeld is de Ford Motor Company met een schatting dat één procent toename in loyaliteit, $\$ 100$ miljoen waard is. Daar komt nog bij dat eenmaal loyale klanten minder marketinginspanningen vragen. De vrijgekomen middelen kunnen beter worden ingezet om nieuwe producten of diensten te ontwikkelen of nieuwe klanten aan te trekken. Uit onderzoek in een aantal branches (in de VS) blijkt dat een toename van $5 \%$ in loyaliteit leidt tot een gemiddelde toename van $73 \%$ in lifetime winst per klant.

\section{Marketing managementvelden}

Hoe nu verder? Uitgaande van de klantbeleving en doelstellingen die impliciet zijn vervat in de marketingmaatstaven, staat het marketing management voor de uitdaging om ervoor te zorgen dat de kennis over de markt en de klanten wordt aangewend. Ik zal een drietal marketing managementvelden onderscheiden warbinnen een aantal beslissingen wordt genomen, waarmee de organisatie kan worden bijgestuurd. De definitie van deze marketing managementvelden zou ik willen introduceren aan de hand van een voorbeeld uit de bigh-tech industrie, gebaseerd op onderzoek van De Ruyter, Moorman \& Lemmink (1999). Om het belang van deze velden aan te tonen worden ze in deze studie ook gekoppeld aan kenmerken van de relatie en resultaten van de onderneming, in termen van loyaliteit.

Case: High-tech onderneming en relatiemanagement

Het introduceren van nieuwe technologieën is vaak een riskante aangelegenheid. De situatie wordt meestal gekenmerkt door geweldig hoge investeringen in onderzoek en ontwikkeling. De vertraagde 
adoptie van producten door consumenten en de gelijktijdige ontwikkeling van producten of systemen door de concurrentie kan lelijk roet in het eten gooien. Denk bijvoorbeeld aan de introductie in het verleden van het V2000 video systeem of de digitale DAT tapes. Een succesvol voorbeeld is de introductie van de CD. Met andere woorden, de omgeving van bigh-tech ondernemingen is waak erg onzeker, fluctueert hevig en zorgt derhalve voor veel risico bij zowel anbieders als vragers (Beard \& Easingwood 1992). Aanbieders van high-tech producten moeten vaak de technologische scepsis pareren die klanten tentoonspreiden, en bovendien rekening houden met vertraagd adopteren van nieuwe technologieën en introductie van nog weer nieuwere technologieën door concurrenten. Aan de andere kant is het zo dat klanten vaak zogenaamde switching costs ervaren vanwege de specifie12 ke gedane investeringen en commitment bezitten ten aanzien van gekozen technologieën en/of aanbieders. Aangezien het aantal aanbieders meestal beperkt is in dit soort markten zijn zowel de genoemde switcbing barrières als de onderlinge afhankelijkheid meestal hoog. Veel aanbieders streven derhalve naar een sterke band met hun klanten. Verder blijkt dat naast de eigenschappen van het bigh-tech product zelf, de expertise van de verkopers, de after-sales support en service en communicatie tussen de partijen, essentiële ingrediënten voor succes zijn (Mayer 1983, Shaw, Giglierano \& Kallis 1989). Het hebben van uitgebreide contractbesprekingen, onderhandelingen en contacten in verband met onderhoud over en weer, leidt vaak tot een situatie van een veelheid aan contacten tussen medewerkers van aanbieders en klanten, waarbij communicatie en samenwerking belangrijk zijn (Cunningham \& Tynon 1993, Gummesson 1987). De complexiteit van de markt en de risico's die daarmee gepaard gaan leidt ertoe dat aanbieders van bigh-tech producten gerichte keuzes dienen te maken bij het aanwenden van middelen. Naast investeren in product en servicekwaliteit is dit bijvoorbeeld investeren in het verhogen van de switch-barrières voor klanten het investeren in het instandhouden van relaties (bijwoorbeeld door het bieden van meer account support). Dit 
laatste wordt juist als nuttig ervaren als er sprake is van "externe" omgevingsonzekerheid (op basis van bijwoorbeeld de transactiekostentheorie in Noordewier, John \& Nevin 1990) zoals in deze case: Dergelijke investeringen leiden altijd tot financiële en niet-financiële resultaten. Vooral concepten als commitment, trouw en loyaliteit worden veelal genoemd als niet-financiële resultaten en als belangrijke bouwstenen van een relatie. Voor een overzicht van de variabelen die gebruikt zijn in dit voorbeeld wordt verwezen naar Figuur 1. Voordat nu de uitkomsten van deze studie worden behandeld zal eerst nog eens het model nader worden toegelicht. Een belangrijk element van het model is de centrale rol van de relatie tussen organisatie en klanten. Het belang van relaties met klanten als onderdeel van de strategie van organisaties is algemeen erkend. Eerst in industriẻle markten (Bitner 1990), maar later ook in consumentenmarkten (Iacobucci, Ostrom, Braig \& Bezjian-Avery 1996). Wilson (1995, pp. 335-336) merkt op dat "relationships bave become strategic and the process of relationship development is accelerated as firms strive to create relationships to acbieve their goals". In industriële markten komt relatievorming tot uiting in het ontstaan van integrale netwerken van klanten en aanbieders, account managers en frequente transacties. Weitz \& Jap (1995) concluderen dat de aandacht voor relatiemanagement gevat kan wor* den in een "werk" metafoor; ondernemingen werken aan hun relatie met consumenten. Om die reden is er in onderzoek veel nadruk gelegd op persoonlijke relaties tussen account en sales management en klanten. In industriële markten wordt het persoonlijke contact veelal gezien als de belangrijkste bron van informatie. In consumentenmarkten willen consumenten steeds meer erkend worden en individucel benaderd worden door aanbieders (Peppers \& Rogers 1993). Daarbij is communicatie en samenwerking van groot belang (Anderson \& Narus 1990). Dit uit zich onder meer in het harmonieus oplossen van conflicten door aanpassing van beide partijen (Achrol 1997 voor industriële markten). 
Relaties tussen partijen ontstaan niet willekeurig, maar ontwikkelen zich in de tijd. Dit proces kan worden beschreven aan de hand van een vijftal fasen (Scanzoni 1979). De eerste fase is de bewustwordingsfase. Deze fase kenmerkt zich door de bewustwording van de andere partij die mogelijk nuttig kan zijn. Daarna komt de exploratiefase, die zich kenmerkt door het zoeken naar en uitproberen van andere partijen. De derde fase is de expansiefase, waarin een steeds sterkere mate van onderlinge afhankelijkheid ontstaat en de relatie steeds nuttiger wordt. Er ontstaat nu een sfeer van vertrouwen en er ontstaat commitment tussen de partijen. Commitment kan beschouwd worden als het meest wenselijke kenmerk van een relatie. Partijen zijn tevreden, leveren beide een bijdrage, sluiten andere partijen met vergelijkbare aanbiedingen uit en hebben de intentie de relatie te continueren. In deze fase komt in wezen de optimale invulling wan de relatie tot stand. Commitment vormt als het ware het "kloppend hart" van de relatie. De vijfde en laatste fase is de ontbindingsfase. Er ontstaat ontevredenheid en het ontbinden van de relatie levert meer op dan het continueren ervan: Zo kan de ontbindingsfase "hartverscheurend" zijn.

Vervolgens is het van belang om de invloed van de genoemde marketing managementvelden op vooral commitment, maar ook op vertrouwen en loyaliteit te specificeren. Commitment heeft te maken met de motivatie om een relatie te continueren. Er kan onderscheid worden gemaakt tussen affectieve en calculatieve commitment (Kumar, Hibbard \& Stern 1994, Kumar, Scheer \& Steenkamp 1995). Affectieve commitment ${ }^{1}$ geeft de mate weer waarin klanten de relatie wensen te behouden, en is gebaseerd op een positief gevoel ten opzichte van de aanbieder. Calculatief commitment behelst een negatieve motivatie en refereert aan het anhouden van de relatie omdat het moeilijk is de huidige relatie te vervangen omdat niet dezelfde gewenste middelen en

${ }^{1}$ In deze oratie zal zowel de omschrijving gevoelsmatige binding als affectieve commitment gebruikt worden voor hetzelfde concept. 
uitkomsten kunnen worden gevonden buiten de relatie. Als gevolg van de gewenste continuitteit in de relatie zullen partners meer bereid zijn samen te werken en doelen te bereiken die voor beiden voordelig zijn. Door lange termijn relaties en vertrouwen kan ook bijvoorbeeld opportunistisch gedrag van de klant worden verkleind. Dit alles leidt tot loyaliteit van de klant aan de onderneming, waarbij in deze case de intentie om in de relatie te blijven als marketing prestatievariabele wordt gebruikt.

Figuur 1. Variabelen in bet model dat verbanden legt tussen de drie managementvelden, de bourestenen van de relatie en loyaliteit.

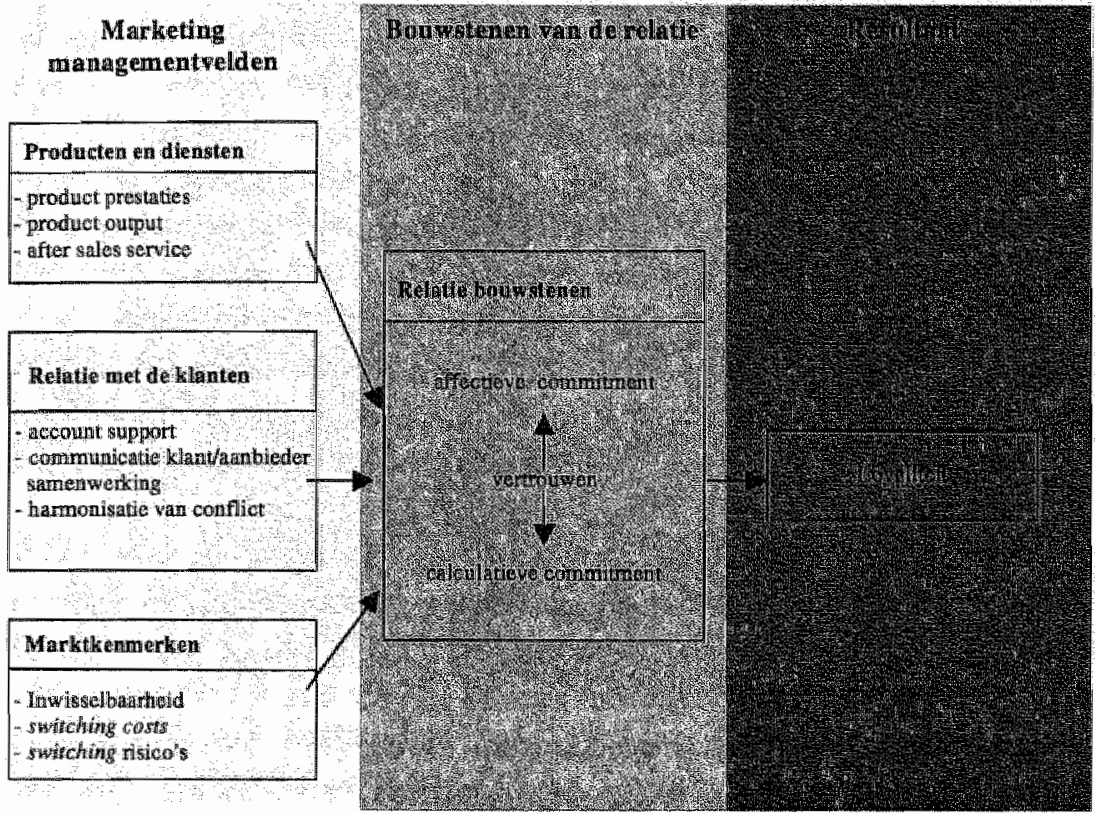


Het bovenstaande model is toegepast bij een Nederlandse fabrikant wan VHV (Very High Volume) kopieermachines. De in Figuur 1 genoemde begrippen zijn gemeten aan de hand van een schriftelijke wragenlijst bij klanten. De steekproef omvatte 1465 bedrijfsklanten in Nederland in bezit van minstens één VHV kopieermachine. De respons bedroeg 491 (34\%). Vervolgens is het model geschat met behulp van LISREL 8, waarbij de in Figuur 1 vermelde subschalen geaggregeerd zijn naar de marketing managementvelden: producten en diensten, relatie met de klanten en marktkenmerken (vergelijk de procedure in Mathieu 1991). De fit van het model bleek goed te zijn en gaf derhalve adequate schattingen van de effecten. De resultaten van deze analyse met de parameterschattingen van de verschillende verbanden zijn weergegeven in Figuur 2. Opvallend is het directe effect van de productkenmerken op loyaliteit. Blijkbaar speelt het product zelf een belangrijke directe rol, en speelt vertrouwen een centrale rol. Uit de modelschattingen blijkt een positief effect op bet affectieve commitment en een negatief effect op het calculatieve commitment. Dit is te interpreteren als het negatieve effect op een "gedwongen, contractueel vastgelegde" relatieperceptie. Blijkbaar noodzaakt minder vertrouwen hardere calculatieve overeenkomsten, en kan in situaties van veel vertrouwen worden volstaan met minder harde contractuele afspraken. Opvallend is ook het uiteindelijke sterke effect van affectieve commitment op loyaliteit.

Hieruit concluderen wij dat de leverancier van bigh-tech producten een drietal velden kan onderscheiden voor investeringen. Investeren in het product zelf, bijvoorbeeld door verbetering van de prestaties en betere ondersteuning door middel van de service e.d. levert een direct bijdrage aan de loyaliteit van klanten. Bovendien wordt het vertrouwen in de organisatie vergroot. Continue vernieuwing leidt tot vertrouwen in de toekomst, en ook de affectieve binding met de organisatie wordt indirect vergroot.. Investeren in de verbetering van de relatie, door middel van het opzetten van een accountmanagement systeem, of verbetering van de onderlinge communicatie leidt vooral 
tot meer vertrouwen en een affectieve binding. Investeren in marktkenmerken leidt tot affectieve, maar vooral tot calculatieve commitment, bijvoorbeeld door producten duidelijk anders te positioneren dan de concurrentie, of door het vergroten van exit-barrières via bijvoorbeeld het afsluiten van contracten voor langere duur of het introduceren van op maat gesneden systemen bij de klant.

Figuur 2. Resultaten van bet model, toepast op een Nederlandse bigh-tech ondermeming.

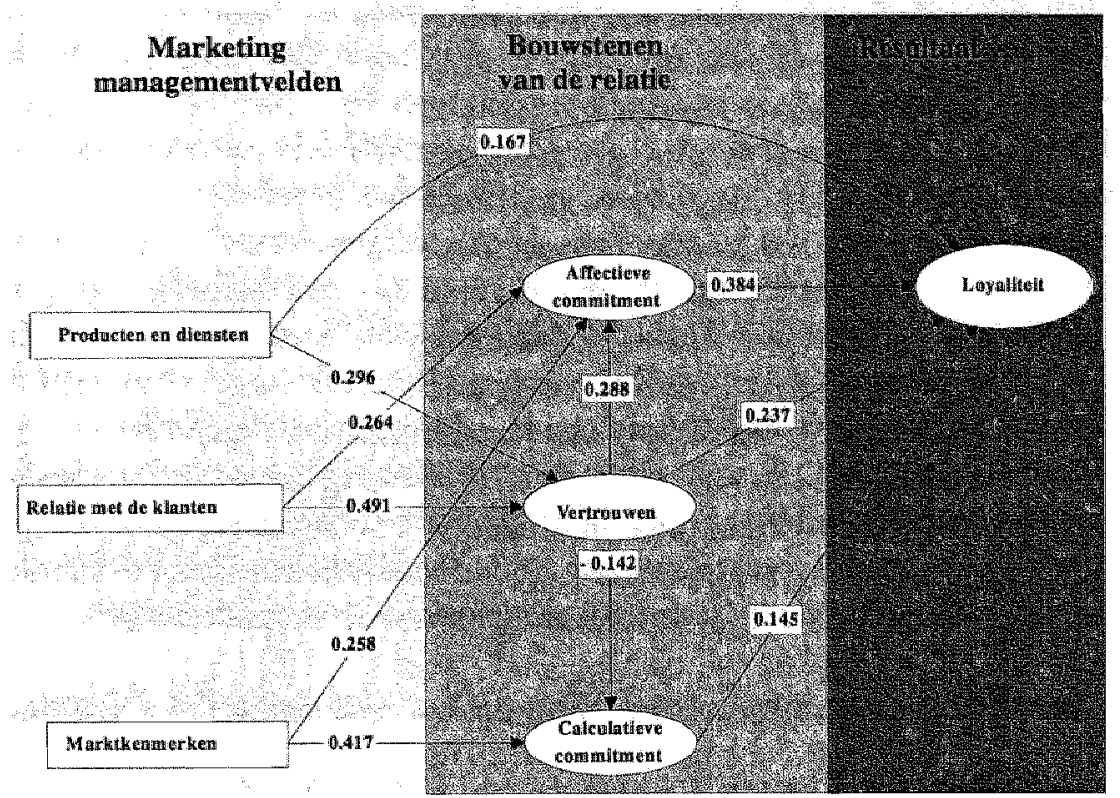

Uit deze case kan worden geconcludeerd dat:

1. De affectieve commitment, ofwel de gevoelsmatige component van de binding tussen klanten en afnemers, zelfs in de hierboven be- 
studeerde relatie in een industriële markt met zakelijke klanten een belangrijke drijfveer is van loyaliteit van klanten.

2. De onderneming over een aantal marketing managementinstrumenten beschikt waarmee de relatie kan worden verstevigd, te weten het product en de service, de relatie met de consument en de marktkenmerken.

3. Vertrouwen een centrale rol speelt in relaties.

De marketing managementvelden kunnen nu worden gezien als de "knoppen" waarmee de organisatie wordt bestuurd en waarmee verschillende scenario's kunnen worden geanalyseerd. Bijvoorbeeld door meer te investeren in het product of de dienst wordt zichtbaar via welke weg een grotere loyaliteit en (financiële) opbrengst ontstaat. Evenals bij investeringsbeslissingen bij bijvoorbeeld uitbreiding van 18 capaciteit wan productiemiddelen, is ook in het geval van consumentenrelaties een gevoeligheidsanalyse te overwegen. Investeren we volgend jaar in een sterke relatie met klanten of ontwikkelen we een nieuwe productvariant? Door middel van de "knoppen" metafoor wordt het verband tussen de instrumenten van het marketing management, de attitudes van consumenten en de financiële resultaten expliciet gemaakt. De ontwikkeling en verfijning van deze verbanden is naar mijn idee een belangrijke richting voor toekomstig onderzoek. In het navolgende vraag ik me af of met behulp van bovenstaande theorie iets te zeggen valt over een aantal recente ontwikkelingen.

\section{Marketing managementvelden en recente ontwikk elingen}

Op basis van voorgaande bevindingen zou ik willen komen tot een beschrijving van een drietal recente ontwikkelingen en de consequenties hiervan voor het marketing management. Recente ontwikkelingen ziju:"

1. Ervaringen van klanten worden steeds belangrijker in vergelijking met de kenmerken van het fysieke product. Ik zal andacht besteden aan het beter leren begrijpen van de klantervaring en klant- 
perceptie tijdens de interactie met de aanbieder. Daarbij komen de volgende begrippen aan de orde: $\mathrm{kwaliteit}$ van het product of de dienst, tevredenheid, emotie en loyaliteit van de consument. Een hele belangrijke en ingrijpende ontwikkeling is de invloed van nieuwe technologische mogelijkheden op het interactieproces tussen aanbieders en consumenten. Immers, nieuwe productie- en informatietechnologieën kunnen van invloed zijn op de wijze waarop het product of de dienst wordt aangeboden en kunnen zelfs ingrijpen in het traditionele beslissingsproces bij consumenten. De nieuwe wijze van aanbieden zou ook invloed kunnen hebben op de rol van werknemers in de organisatie. Met name zullen er consequenties zijn voor de groep werknemers die in direct contact met de klant staan. Door de directe contacten via bijvoorbeeld Internet verandert de inhoud van het werk voor een deel van dit personeel van direct klantencontact naar elektronisch klantencontact.

2. De houding van het personeel van ondernemingen die in direct contact staan met de klanten wordt belangrijker.

3. Definiëring van indicatoren voor marketingresultaten ten behoeve van het managen van organisaties. Niet alleen de harde criteria zijn van belang (ROI, marktaandeel, winst), maar ook is er een duidelijke behoefte an nieuwe, innovatieve marketing prestatiemaatstaven zoals de eerder genoemde commitment en loyaliteit.

\subsection{Beter begrijpen van ervaringen van de consument}

Het gedrag van consumenten wordt steeds grilliger, complexer en kritischer (zie Kahn 1998). Eén van de manieren om hieraan tegemoet te komen is het concurreren met een strategie van het op de markt brengen van veel variêteiten (Kahn 1998, Van Trijp 1995). Enerzijds maakt dit het meer waarschijnlijk dat er een product op de markt is dat de klanten aanspreekt. Anderzijds, kunnen klanten gebruik maken van verschillende opties op verschillende tijdstippen. Dit appel- 
leert aan het zogenaamde wariety seeking gedrag van de consument. Dat is de neiging van consumenten om diversiteit te zoeken in de producten of diensten die worden genoten (Givon 1984, Kahn, Kalwani \& Morrison 1986, Van Trijp 1995). De meest genoemde verklaring voor dit gedrag is het bereiken van een verzadiging in de consumptie of het zoeken naar een nieuwe ervaring of uitdaging, of intellectuele nieuwsgierigheid. Het resultaat van een dergelijke strategie kan tot uitdrukking komen in een groter marktaandeel of zelfs een grotere primaire vraag naar het product of de productcategorie. Het is voor de aanbieder relevant op de hoogte te zijn van dergelijke steeds grilliger verlopende ontwikkelingen om in staat te zijn erop in te spelen. Dit vergt constant leren van en aanpassen aan de consument. Het onderhouden van een goede relatie is een wijze om hieraan tegemoet

20 te komen. En als er iets zeker is in een relatie is het de dynamiek. Dynamiek komt eveneens tot uitdrukking op het niveau van de interactie tussen medewerker en klant. Dit kan worden geillustreerd aan de hand van een onderzoek in winkelsettings (Lemmink \& Mattsson 1998). Het blijkt dat verkopers, zonder dat sprake is van een daadwerkelijke aankoop van een klant, door het geven van informatie en het helpen bij problemen van de klant, een positief gevoel van warmte teweeg kan brengen. In tweede instantie leidt dat tot een grotere loyaliteit van de klant. Een microanalyse van het verkoopproces van seconde tot seconde laat zien dat het gedrag en de houding van verkopers in sterke mate het gevoel van de klant kan beïnvloeden, en dat dit in sterke mate de loyaliteit beînvloedt.

Een andere observatie is dat de klant te maken krijgt (ook in consumentenmarkten) met veel wisselende contacten met een aanbieder. Bijvoorbeeld bij een bank. Het is niet moeilijk om een veelheid aan al dan niet persoonlijke contacten met klanten voor te stellen. Een opsomming: de baliemedewerker, de hypotheekadviseur, de telefoniste, de rekening-courant administratie, rekening courant afschriften, bijsluiters, brochures, reclame-uitingen en Websites etc. Voor de organisatie zijn dat even zovele contactmomenten: orderverwerking, factu- 
rering, servicecontacten, distributie, transport, administreren van marketingacties, produceren van reclame-uitingen, Websites bijhouden etc. Dit geldt niet alleen voor dienstverienende bedrijven, maar in grote mate ook voor merkartikelfabrikanten, winkelketens, etc.

Eén van de recente ontwikkelingen is dat door Internettechnologie het persoonlijke contact gesubstitueerd wordt door contact via Websites. De vraag, en tevens een uitdaging voor onderzoek, is nu of het daadwerkelijke persoonlijke contact een unieke bijdrage levert aan de binding die klanten ervaren of dat de gevoelsmatige component ook elektronisch nagebootst kan worden. Om de ontwikkelingen op dit gebied te illustreren volgt nu het voorbeeld van Firefly.

Firefly case

Zoals eerder is aangegeven is het voor consumenten die voor een aankoopbeslissing staan van belang van hun voorkeuren bewust te worden, zodat een keuze gemaakt kan worden uit verschillende aangeboden opties. Het is in het belang van de aanbieder consumenten te helpen bij het maken van deze keuzes. Traditioneel gebeurt dit door het geven van informatie over producten en diensten voordat het product of dienst wordt gekocht. Voorbeelden van deze zogenaamde marketing mix instrumenten die de onderneming kan hanteren zijn: reclame-uitingen, informatiebrochures, telefonische informatienummers, websites en winkeldisplays. Het ligt voor de hand dat een onderneming studie maakt van de mogelijke optimale interactiemomenten met (potentiële) consumenten. Daarbij kan ruwweg onderscheid gemakkt worden tussen systemen die een persoonlijke benadering tot stand brengen via "als,dan" regels en systemen die gebaseerd zijn op de zgn. collaborative filtering. Een voorbeeld van een "als, dan" benadering is software die gebruilkt wordt om Websites te personifiëren. Door gebruik te maken van het bekende profiel van de consument kan een op maat gemaakt boodschap worden verstuurd naar die online consument. De onderneming stelt hierbij de criteria vast en be- 
slist in feite over welke informatie naar wie gaat. Een voorbeeld van een recente innovatie op dat gebied, waarbij de klanten in feite hun eigen dynamiek bepalen, is de ontwikkeling van collaborative filtering, een methode die door de Website van Firefly wordt gebruikt. Het werkt als volgt. Consumenten geven hun voorkeuren aan voor favoriete speelfilms of $\mathrm{CD}^{\prime}$ s door middel van een selectie uit een bestaande lijst. Daarna worden deze consumenten gepaard aan een andere, bestaande groep van consumenten met een vergelijkbaar profiel en waarvan de huidige voorkeuren eveneens bekend zijn. Op deze wijze kan Firefly een groep nieuwe klanten de aanschaf van een bepaalde CD of speelfilm aanbevelen, met een grote kans dat klanten zich hier ook daadwerkelijk voor interesseren. Normaliter was dit productaanbod niet onder de aandacht van de consument gebracht. Deze benadering 22 geldt vooral voor producten en diensten waarbij de persoonlijke smaak van de consument een belangrijke rol speelt. De verleiding voor bedrijven is wellicht groot om invloed te gaan uitoefenen op de aanbevelingen die gedaan worden. Het ligt voor de hand dat een dergelijke strategie tot een vertrouwensbreuk kan leiden met de consument.

Uiteindelijk zal persoonlijke informatie en op maat gesneden aanbiedingen de prijsgevoeligheid van consumenten verlagen (Degheratu, Rangaswamy \& Wu 1998). De eerste resultaten van onderzoek laten nu al zien dat zogenaamde smart agents in staat zijn vertrouwen en commitment op te bouwen (Urban 1998) zonder dat daadwerkelijk sprake is van persoonlijk contact.

De advocaat van de duivel zou nu iets gaan roepen over de bindende eigenschappen van lage prijzen. Is het niet zo dat juist lage prijzen klanten bindt? Meestal leidt dit tot korte termijn effecten; m.a.w. incidenteel en ad boc verandert het gedrag van consumenten, waarna weer wordt teruggevallen op de "oude" relaties. Er is bewijs uit experimenten dat loyaliteit wordt opgebouwd door middel van persoonlijke dienstverlening en het geven van kwalitatief goede en op maat 
gesneden informatie, en niet door middel van het verlagen van de prijs. Het volgende experiment is een goede illustratie en is afkomstig van Lynch \& Ariely (1999).

Uitgangpunt in deze studie was dat het gebruik van technologieën die het mogelijk maken gemakkelijk prijsvergelijkingen te maken tussen identieke producten, zal leiden tot een lager prijsniveau, ergo een verhoogde prijsconcurrentie. Deze situatie kan goed worden nagebootst door in Websites de mogelijkheid van prijsvergelijkingen op te nemen. Voorbeelden van dergelijke sites zijn Websearch, Excite, Pricescan en specifiek voor reizen Expedia en Travelocity. Het experiment bestond eruit studenten een keuze te laten maken uit een aanbod van verschillende wijnmerken. Vervolgens werd gevraagd om wijnen te kopen via twee elkaar beconcurrerende elektronische annbieders van wijn (Jubilee en Dyonisus). Honderd wijnmerken waren beschikbaar. Elke winkel had 60 wijnen in haar assortiment, 20 overlappend met de andere winkel en 40 unieke soorten. De vergelijkbaarheid tussen de twee elektronische aanbieders werd gemanipuleerd en was moeilijk of gemakkelijk gemaakt. Zelfs al werd het vergelijken tussen de winkels gemakkelijk gemaakt, het marktaandeel van de in beide winkels verkochte wijnen was disproportioneel hoog. In het geval de klant zich volledig zou realiseren dat er gemeenschappelijke wijnen werden aangeboden zou het marktaandeel van deze wijnen $1 / 5$ zijn, en niet $1 / 3$ (vergelijk het klassieke "similarity" effect van Tversky 1972). Gemeenschappelijke wijnen hadden een aanzienlijk groter marktaandeel dan $20 \%$ in zowel de situatie van moeilijke als gemakkelijke vergelijkbaarheid van het aanbod. Er was dus sprake van positieve returns to distribution, zelfs in het geval van transparante markten. Exclusieve distributie van producten is dus niet zonder "kosten".

De zoekkosten naar informatie over de kwaliteit in transparante omgevingen zijn eveneens lager. Op de lange termijn zal er veel meer differentiatie ontstaan door verschillen in kwaliteit en dienstverlening, veroorzaakt via door consumenten opgemerkte variatie in kwaliteit en vertrouwen in merken. Dit wordt mede veroorzaakt door het 
leervermogen van aanbieders. Deze kunnen, zoals eerder is aangegeven, leren van de voorkeuren en ervaringen van consumenten. Die gegevens kunnen vervolgens worden gebruikt om betere en meer gerichte informatie te verschaffen over alternatieven die tot maximalisatie van het nut in de ogen van consumenten zou kunnen leiden. Als anbieders het de klant gemakkelijker maken om informatie te verkrijgen over prijzen, $k$ waliteiten en vergelijkingen tussen aanbieders, dan zal dat niet tot een grotere prijsgevoeligheid leiden. De prijsgevoeligheid werd juist kleiner naarmate de kwaliteitsinformatie bruikbaarder was. Daarnaast concluderen Lynch \& Ariely (1999) dat consumenten meer transparantheid prettiger vinden en dat het heterogene aanbod beter afgestemd kan worden op de heterogene persoonlijke smaken, hetgeen leidde tot een significant hogere loyaliteit.

\subsection{De houding van het personeel}

De relatie met de klanten gat in veel gevallen gepaard met bemoeie. nis van medewerkers van een organisatie, denk aan verkopers, servicepersoneel, dienstverlenend personeel etc. Het is belangrijl om kwalitatief goede prestaties te leveren. Een mogelijke wijze om personeel te motiveren en te stimuleren om prestaties te leveren is empowerment. In essentie is dat: "..the reverse of doing things by the book" (Zemke \& Schaaf 1989, p. 68). Meestal wordt onderscheid gemaakt tussen competentie en autonomie (Chiles \& Zorn 1995). Met andere woorden, de werknemer heeft de kennis om het werk goed te doen, en heeft bovendien de nodige vrijheid om beslissingen te nemen. $\mathrm{Nu}$ blijkt dat er een aantal voor- en nadelen zijn van het empoweren van medewerkers (Bowen \& Lawler III 1995). Nadelen zijn dat er moet worden geïnvesteerd in training en dat medewerkers zorgvuldig moeten worden geselecteerd. Daarnaast zullen de personeelskosten hoger zijn in verband met de grotere kennis en verantwoordelijkheid. Verder ligt het voor de hand dat er enige inconsistentie ontstaat in het behandelen van klanten. Wat voor de één gerealiseerd is, wordt ook 
door de ander gewenst. Bovendien kost het ingaan op specifieke wensen ook tijd. Op deze wijze kan empowerment leiden tot het langzaam en inconsistent bedienen van de klant. Daartegenover staat een groot aantal voordelen:

- Snellere en directe respons op klantenbehoeften op het moment dat producten of diensten worden verkocht.

- Medewerkers voelen zich beter in hun werk.

- Medewerkers doen hun werk met klanten met meer enthousiasme en warmte.

- Medewerkers zijn een bron van ideeën over hoe de klant tegemoet getreden dient te worden.

Uit onderzoek van Hartline \& Ferrel (1996) blijkt dat er een positief verband is tussen empowerment en commitment van de werknemer richting organisatie. Wetzels (1998) en Wetzels, De Ruyter \& Lemmink (1999) concluderen verder dat empowerment een sterk positief effect heeft op de tevredenheid van de werknemer met zijn of haar baan en de kwaliteit van de prestaties richting klanten. Een goede illustratie hier is de "zelfsturende" buschauffeur. Bij een aantal busbedrijven wordt geëxperimenteerd met het geven van meer verantwoordelijkheid aan buschauffeurs. $\mathrm{Zij}$ worden o.a. betrokken bij de planning van de routes en beslissen mee over de uitvoering van de bus. Daarnaast hebben zij meer vrijheid in het adviseren van en hulp bieden aan reizigers. Hieruit concluderen we dan ook dat empowerment een sterk effect heeft op "het hart voor de zaak hebben" van werknemers. Bovendien zijn door betere prestaties de klanten beter af.

\subsection{Marketing resultaten}

Marketing is een functie die meestal gemeten wordt aan de hand van haar primaire missie, het creëren en behouden van klanten. Oorspronkelijk wordt de prestatie van een organisatie gemeten in omzet, omzetgroei, beheersing van marges eni marktaandeel (Ghormley 
1999). Meer innovatieve, op verschillende manieren meetbare, grootheden zijn: lange termijn waarde van een klantenkring, van distributiekanalen en van een merk. Deze laatste waarde ontstaat doordat marktpartijen waarde toekennen aan het product of de dienst. De merkwaarde kan worden verhoogd door het investeren in de beleving van een product of dienst door klanten of marktpartijen in het distributiekanaal. Andere, meer subjectieve, prestatiemaatstaven zijn vertrouwen, commitment en loyaliteit. In de genoemde bigh-tech case is al aangegeven dat deze concepten belangrijk zijn voor het verklaren van de loyaliteit. In het navolgende zal ik antonen dat deze drie concepten eveneens van onschatbare waarde zijn als marketing prestatiemaatstaf.

Van oudsher ligt de nadruk van marketing op het verkopen van het product of de dienst zelf: de kenmerken van het product en de bijbehorende service. Uiteraard is ook de prijs onlosmakelijk verbonden aan het product, maar speelt in veel markten niet die belangrijke rol die het vaak wordt toegedicht. Ondernemingen trachten zich te distantiëren van prijsconcurrentie door te gaan concurreren op juist alles behalve de prijs. Zo komen opbrengsten vaak voor een groot deel uit additionele toegevoegde dienstverlening. Denk aan onderhoud c.q. after-sales service bij auto's en computers (Vandermerwe \& Lovelock 1994, Zeithaml \& Bitner 1996). Het vertrouwen in het product hangt niet alleen af van het product zelf, maar van zowel de product- als de servicekwaliteit. Bij het product kan daarbij onderscheid worden gemaakt tussen de kwaliteiten van het fysieke product en de prestaties die met dat product zijn behaald. Vertrouwen wordt omschreven als het geloof van de consument in de eerlijkheid van de aanbieder en het zodanig vertrouwen van de aanbieder dat deze geen voor de consument nadelige acties zal gaan ondernemen in de toekomst. Vertrouwen heeft dus een retrospectieve en een prospectieve component. Het zegt dus iets over het verleden en over de toekomst, en kan dus worden beschouwd als een uitstekende monitorvariabele, als onderdeel van een "early warning" system voor het management van onderne- 
mingen. Gebrek aan vertrouwen nu, kan in de toekomst desastreus zijn.

\section{Conclusies}

In grote lijnen kunnen de volgende conclusies worden getrokken:

- Een blijvend sterke positie van een onderneming op de markt steunt sterk op "het hart voor de zaak" hebben van medewerkers en "het hart voor de zaak" hebben van de klanten. Onderzoek naar deze factoren blijft belangrijk binnen de marketingdiscipline. Ook bij de introductie van nieuwe technologieën en veranderende marktstructuren.

- Met de opkomst van e-commerce en Webmarketing is het mogelijk voor een onderneming om de affectieve component van een relatie te handhaven. Daarvoor dient echter wel een beroep te worden gedaan op de moderne analysemogelijkheden van markt- en klantgegevens (vgl. collaborative filtering).

- Er is meer onderzoek nodig naar de details van een relatie. Het gebruik van video-observaties en gedragcoderingen uit de psychologie in eerder marketingonderzoek hebben hun nut al bewezen.

- Modellen die expliciet de relatie leggen tussen het instrumentarium van het marketing management, attitudes van consumenten en financiële resultaten moeten verder ontwikkeld en getoetst worden. Dit is een sterke uitdaging voor ons onderzoek.

- Meer onderzoek is nodig naar alternatieve prestatiemaatstaven, daarbij is het belangrijk zich te realiseren dat maatstaven die dicht bij de beleving van klanten staan een waardevol "early warning system" vertegenwoordigen. Daarom is monitoring van deze gegevens noodzakelijk. De mythe van het moeilijk meetbaar zijn van deze variabelen moet de wereld uit!

Binnen de sectie marketing en marktonderzoek zullen we de komende tijd met verve deze uitdagingen aanpakken. De start is al gemaakt. 
Op dit moment wordt aan het onderzoek gewerkt door o.a. zes promovendi op gebieden als: de ontwikkeling van nieuwe elektronische diensten, de relatie tussen verkopers en klanten, het gebruik van klanteninformatie door managers, het dienstverleningsproces door teams, customer interaction centers, en return on quality (RoQ) vraagstukken. Dit gebeurt met veel enthousiasme en met medewerking van cen antal organisaties. Hier wil ik met name de lange, uiterst waardevol gebleken, onderzoekstraditie met Océ noemen. 


\section{Dankwoord}

Tot besluit wil ik grag een dankwoord uitspreken tot de mensen die direct en indirect hebben bijgedragen aan mijn wetenschappelijke vorming. Maar voordat ik dat ga doen wil ik het College van Bestuur van deze universiteit bedanken voor mijn benoeming en het in mij gestelde vertrouwen. Dan zou ik graag als eerste Hans Kasper, acht jaar geleden mijn promotor, mijn voorganger als voorzitter van de sectie Marketing \& Marktonderzoek, en inmiddels directeur van ETI, willen bedanken. Beste Hans, ik dank je voor je collegialiteit en steun vanaf het begin dat we samen in Maastricht begonnen, nu alweer meer dan 14 jaar geleden.

Verder zou ik graag willen uitroepen dat ik trots ben op mijn sectie Marketing \& Marktonderzoek. De afgelopen 3 jaar is er erg veel geïnvesteerd, zowel in tijd als in energie, en in onderzoek, met de nodige klinkende resultaten. I $\mathrm{k}$ wil jullie allemaal bedanken voor jullie bijdrage. Zonder overdrijwing kan ik vaststellen dat we, met ons onderzoeksinstituut MAXX (Maastricht Academic Center for research in Services), de academische top in Europa vertegenwoordigen op het gebied van dienstenmarketing. Ik wil met name Ko de Ruyter bedanken, die de afgelopen jaren een niet te missen sparringpartner was bij het leiden van de sectie. Je tomeloze energie heeft aanstekelijk gewerkt, en ik zou je dan ook expliciet willen danken voor je inzet en hulp. Dan rest er nog één collega die ik met name wil noemen, en die hier helaas niet aanwezig kan zijn, maar die ik volgende week in Australië ga opzoeken, Jan Mattsson. Zijn vriendschap en speciale manier van werken heeft me over de grenzen van het vakgebied heen laten kijken. Mijn dank hiervoor.

Tot slot mijn familie. Het is verwonderlijk dat mijn broer Koen, verbonden aan de Rijksuniversiteit Groningen, hoewel op een heel ander vakgebied (bewegingswetenschappen), met hetzelfde instrumentarium bezig is analyses te maken van menselijk gedrag. Hij in een sport en 
revalidatieomgeving, ik in een commerciële omgeving. Koen, bedankt voot de discussies over de raakwlakken van ons beider onderzoek. Vervolgens dank ik mijn ouders. Zij hebben mij in de gelegenheid gesteld de nodige studies te volgen, en hebben mij daar op alle mogelijke manieren in gesteund. Mijn schoonouders uit Roermond wil ik ook danken. $\mathrm{Zij}$ waren de eerste maanden de pied-à-terre in Limburg bij mijn overstap van de destijds nog Centrale Directie van de PTT in Den Haag, naar de Universiteit Maastricht. En dan, eindelijk, mag ik Marian, Lotte en Ester bedanken. Dames, ik geniet elke dag van jullie aanwezigheid en meeleven. Zonder jullie onvoorwaardelijke steun en relativeringsvermogen zou ik hier niet staan. Mijn hart ligt bij jullie zaak.

$\overline{30}$ Ik beb gezegd. 


\section{Literatuurlijst}

Aaker, D.A., 1992, The value of brand equity, Journal of Business Strategy, 13, July/August, 27-32.

Aaker D.A. \& R. Jacobson, 1994, The financial information content of perceived quality, Journal of Marketing Research, 31, May, 191-201.

Achrol, R.S., 1997, Changes in the theory of interorganizational relations in marketing: toward a network paradigm, Joumal of the Academy of Marketing Science, 25, 56-71.

Anderson, E.W., C. Fornell \& D.R. Lehmann, 1994, Customer satisfaction, market share, and profitability: findings from Sweden, Journal of Marketing, 58, July, 53-66.

Anderson, J.C. \& J.A. Narus, 1990, A model of distributor firm and manufacturer firm working partnerships, Joumal of Marketing, 54, January, 42-58.

Beard, C.R. \& C.J. Easingwood, 1992, Sources of competitive advantage for the marketing of high-tech products and processes in the UK, European Journal of Marketing, 26, 7-20.

Bitner, M.J., 1990, Evaluating service encounters: the effects of physical surroundings and employee responses, Joumal of Marketing, 54, January, 71-84.

Bowen, D.E. \& E.E. Lawler II, 1995, Organizing for service: empowerment or production line?, in: W.J. Glynn $\&$ J.G. Barnes (eds.), Understanding Services Management, John Wiley \& Sons, Chichester, 269-294.

Capon, N., J.U. Farley \& S. Hoenig, 1990, Determinants of financial performance: a meta-analysis, Management Science, 36 (October), 1143-1159. 
Chiles, A.M. \& T.E. Zorn, 1995, Empowerment in organizations: employees' perceptions of the influences of empowerment, Journal of Applied Communication Research, 23, 1-25.

Cunningham, C. \& C. Tynon, 1993, Electronic trading interorganizational systems and the nature of buyer-seller relationships: the need for a network perspective, International Joumal of Information Management, 3-28.

Davis, S., \& C. Meyer, 1998, Blur, the speed of change in the connected economy, Addison-Wesley, Reading, Massachusetts.

Degheratu, A., A. Rangaswamy, \& J. Wu, 1998, Consumer choice behavior in online and regular stores: the effects of brand name, price and other search attributes, in: D. Hoffman \& J. Little (eds), Collected Working Papers Marketing Science and the Internet, INFORMS MiniConference, MIT, Sloan School of Management.

De Ruyter, K., L. Moorman \& J. Lemmink, 1999; Antecedents of commitment and trust in customer-supplier relationships in high technology markets, Industrial Marketing Management, (forthcoming).

Ghormley, W.A., 1999, Marketing @ "MM", Marketing Science Institute Review, Spring, 3-8.

Giwon, M., 1984, Variety-seeking through brand switching, Marketing Science, 3 (Winter), 1-22.

Gummesson, E., 1987, The new marketing-developing long-term interactive relationships, Long Range Planning, 20, 10-20.

Hartline, M.D. \& O.C. Ferrel, 1996, "The management of customercontact service employees, Jowrnal of Marketing, 60, October, 52-70.

Iacobucci, D., A.L. Ostrom, B.M. Braig \& A. Bezjian-Avery, 1996, A canonical model of consumer evaluations and theoretical bases of expectations, in: T.A. Swartz, D.E. Bowen \& S.W. Brown (eds), Ad. 
vances in services marketing and management: research and practice, 5 , JAI Press, Greenwich \& London, 1-44.

Kahn, B.E., M.U. Kalwani \& D.G. Morrison, 1986, Measuring variety-seeking and reinforcement behaviors using panel data, Journal of Marketing Research, 23 (May), 89-100.

Kahn, B.,1998, Dynamic relationships with customers: high variety strategies, Joumal of the Academy of Marketing Science, 26, 1, 45-53.

Kalyanaram, G. \& J.D.C. Little, 1994, An empirical analysis of latitude of price acceptance in consumer package goods, Joumal of Consumer Research, 21 (December), 408-418.

Kohli, A.K. \& B.J. Jaworski, 1990, Market orientation: the construct, research propositions, and managerial implications, Journal of Marketing, 54, 1-18.

Kumar, N., J.D. Hibbard \& L.W. Stern, 1994, The nature and consequences of marketing channel intermediary commitment, Marketing Science Institute, No. 94-115, Cambridge.

Kumar, N., L.K. Scheer \& J.E.M. Steenkamp, 1995, The effects of perceived interdependence on dealer attitudes, Joumal of Marketing, 32, August, 348-356.

Lemmink, J. \& J. Mattsson, 1998, Warmth during non-productive retail encounters: the hidden side of productivity, International Journal of Research in Marketing, 15, 505-517.

Lynch, J.G. \& D. Ariely, 1999, Electronic shopping for wine: bow search costs for information on price, quality, and store comparison affect consumer price sensitivity, satisfaction with merchandise, and retention, Working Paper, Report 99-104, Marketing Science Institute, Cambridge.

Marketing Science Institute, 1997, Research Priorities 1998-2000, Marketing Science Institute, Cambridge, Massachusetts. 
Mathieu, J.E., 1991, A cross-level nonrecursive model of the antecedents of organizational commitment and satisfaction, Joumal of Applied Psychology, 76, 5, 607-618.

Mayer, W.U., 1983, Situational variables and industrial buying, Journal of Purchasing and Materials Management, Winter, 21-26.

Noordewier, T.G., G. John \& J.R. Nevin, 1990, Performance outcomes of purchasing arrangements in industrial buyer-vendor relationships, Journal of Marketing, 54 (October), 80-93.

Oliver, R.L., 1997, Satisfaction: a behavioral perspective on the consumer, McGraw-Hill, New York.

Peppers, D. \& M. Rogers, 1993, The one to one future: building relati-

34 onships one customer at a time, Currency/Doubleday, New York.

Rust, R.T., A.J. Zahorik \& T.L. Keiningham, 1995, Return on quality (RoQ): making service quality financially accountable, Journal of Marketing, 59 (April), 58-70.

Scanzoni, J., 1979, Social exchange and behavior interdependence, in: R.I. Burgess \& T.L. Huston (eds.), Social Exchange in Developing Relationships, Academic Press, Inc., New York, 61-98.

Shaw, J, J. Giglierano \& J. Kallis, 1989, Marketing complex technical products: the importance of intangible attributes, Industrial Marketing Management, 18, 45-53.

Tversky, A., 1972, Choice by elimination, Joumal of Matbematical Psychology, 9, 341-367.

Urban, G., 1998, Trust based marketing on the Web, in: D. Hoffman \& J. Little (eds.), Collected Working Papers Marketing Science and the Internet, INFORMS Mini-conference, MIT, Sloan School of Management. 
Vandermerwe, S. \& C. Lovelock, 1994, Competing through services. Strategy and implementation, Prentice Hall.

Van Trijp, J.C.M., 1995, Variety-seeking in product choice bebavior: theory with applications in the food domain, Mansholt Studies, 1, Agricultural University, Wageningen.

Weitz, B.A. \& S.D. Jap, 1995, Relationship marketing and distribution channels, Joumal of the Academy of Marketing Science, 4, 23, 305320.

Wetzels, M., 1998, Service Quality in Customer-Employee Relationsbips, Dissertation Maastricht University, Maastricht.

Wetzels, M, K. De Ruyter \& J. Lemmink, 1999, Role stress in aftersales service management, Joumal of Service Research, 2, August, 50-67.

Wilson, D.T., 1995, An integrated model of buyer-seller relationships, Journal of the Academy of Marketing Science, 4, 23, 335-345.

Zeithaml, V.A. \& M.J. Bitner, 1996, Services marketing, McGraw-Hill Companies, Inc., Singapore.

Zemke, R. \& D. Schaaf, 1989, The service edge: 101 companies that profit from customer care, New American Library, New York. 